\title{
GOLGOTHA ON CITY PERIPHERIES: THE PASSION PLAY IN BYDGOSZCZ FORDON
}

\author{
Kamila Baraniecka-Olszewska
}

\begin{abstract}
Passion plays are gaining more and more popularity in Poland. Through participation, the faithful seek answers not only to their religious doubts, but also to the problems of the contemporary world. That is why some Easter play organizers decide to depart from the classic script of Passion plays, based on the Stations of the Cross, and to prepare for the audience performances which interpret political and social processes through the religious story. One such Passion play has been staged for over ten years in Bydgoszcz Fordon in Poland. This article examines how the concept of ritual efficacy can explain the particular impact of the Easter play on its participants.
\end{abstract}

Keywords: Catholicism, contemporary religiosity, efficacy, Passion plays, performance, Poland

This article has two principal purposes. First, I want to present one Polish Passion play that is, in my opinion, worth a separate study: namely the play staged in Bydgoszcz Fordon which is exceptional in comparison with the majority of Passion plays all over the world. And second, through this example I would like to show how religious content is actualized by means of performance. Focusing on three iterations of the Fordon play, I describe three interpretation keys which allow us to grasp the process of actualization of Christ's Passion. Simultaneously I show that the need of actualizing the Passion of Christ and giving it contemporary meanings related to present issues draws from the changing kind of the religious sensitivity of the faithful. Believers seek in the Church for a whole range of experiences, and for answers concerning their everyday problems. The Bydoszcz Fordon passion play is a particular way of providing them with such answers - not, however, from the Catholic Church itself, but through the layman who cooperate with the Church. I would like to place the whole description of the Fordon Passion play within an overarching consideration of the efficacy of rituals/performances and show that in the case of this Easter play we can speak of a very particular kind of performance efficacy which extends beyond our usual understanding of this category, but 
simultaneously answers the question often stated by scholars dealing with efficacy: 'what does performance do?'.

\section{RITUAL/PERFORMANCE EFFICACY AND THE NOTION OF PERFORMATIVITY}

First I would like to introduce and comment on the general idea of the efficacy founded on performativity - of rituals and performances. This constitutes the theoretical framework of my considerations. Although I am aware of the differences between ritual ${ }^{1}$ and performance theories, and though I am aware of problems with sharp distinction between those two interpretative modes and of those two separate (or not) kinds of phenomena ${ }^{2}$ (see e.g. Schechner 1994), notwithstanding, I focus on and present briefly one of the common aspects of both anthropological concepts, namely efficacy. The question of efficacy may be analyzed in reference to the problem of 'what ritual or performance does' (see Lambek 2002: 431) and answered in a very simple and direct way: it brings rain, it transforms a boy into a man, it heals etc. These simple answers are, however, sophistically theorized through the notion of performativity. The most well-known text on the performativity of ritual is Stanley J. Tambiah's A performative approach to ritual (1985). Tambiah describes three kinds of performativity with which we can deal in investigating rituals.

Ritual is performative in the Austinian sense when saying something is also doing something as a conventional act; in the quite different sense of staged performance that uses multiple media by which the participants experience the event intensively; and in the sense of indexical values - I derive this concept of Peirce - being attached and inferred by actors during performance. (Tambiah 1985: 128)

I would like to show that all those aspects of performativity are present in Passion plays, although analogically rather than literarily. Passion plays do not change the status of things in the very Austinian sense, but they have the potential of creating, changing, and transforming things. This may not occur as directly as indicated by Tambiah, but they do evoke new meanings, establish new symbols, and to some degree they transform reality.

In some cases, reflection on ritual/performance efficacy is linked to analysis of the risk inscribed into performance. It appears that if the event is not efficient, it fails (Howe 2000; Schieffelin 1996). That is not, however, the case of Passion plays, since they do not have one particular purpose - e.g. to call down rain, etc. (in their case it is not an efficacy sui generis, as Podemann Sørensen puts 
it 2006: 524), but their efficacy also can be considered in terms of success or failure. This, however, is much more blended in the above-mentioned example, since it derives from the historical, cultural, and social context in which Passion play is presented.

\section{THE PASSION PLAY IN BYGOSZCZ FORDON: A SHORT HISTORY}

Since the fall of Communism, we can observe increasing interest in Poland in participation in Catholic religious events beyond strict liturgical services. ${ }^{3}$ The faithful seek for new kinds of religious experiences and thus for new forms of religious events which could provide those experiences (see Zowczak 2008). That is exactly why Passion plays presented during the Lent and Easter seasons, constituting a part of preparation for approaching Easter liturgical celebrations, are at the same time an attractive way of spending leisure time (KunczyńskaIracka 1988), and become more and more popular. In Poland dozens of Passion plays are staged each year and hundreds of thousands people participate in them in churches, sanctuaries or other sacred (but not only sacred) places. Most of those Easter performances are based on one main script - the Way of the Cross and crucial events from Christ's life which preceded it. The Way of the Cross is for Polish Catholicism one of most important root paradigms; this term, coined by Edit and Victor Turner, refers to elements of religion which "derive from the seminal words and works of the religion's founder, his disciples or companions, and their immediate followers, and constitute the "deposit of faith"' (Turner \& Turner 1978: 10). Most of Polish Passion plays present Christ's story from the Last Supper (some from the entrance to Jerusalem), through prayer in Gethsemane, scenes before Pilate, and culminate either on the Way of the Cross to crucifixion or in the Resurrection. Such presentations of Christ's Passion move the audience deeply; engaging its members particularly because of familiarity of the presented history. People see in those Passion plays exactly what they were taught in their religion classes, and in churches - a story to which they are accustomed and that they have experienced visually through religious images, movies, and religious works of art. ${ }^{4}$ These Passion plays refer to icons of commonly-shared religious images.

Although such performances constitute the majority of Polish Passion plays, there is one more type of Easter play, a type that constitutes a challenge for the audience. Such performances do present main events from the last moments of Christ's life, but their script is much more complicated and grants to viewers the possibility not only to see popular religious images live and on scene, as it were, while at the same time forcing them to reflect on a particular element 
of Christ's Passion, chosen by the author and concretized on stage. Usually it is an element actualizing the message of Jesus' Passion for the contemporary faithful. In this article I would like to describe one Passion play of this latter type: the Easter performance in Bydgoszcz Fordon. ${ }^{5}$ This performance has been staged annually since 2001 on Palm Sunday (a week before Easter Sunday). Its organizers each year present a new script trying to show new and fresh interpretations of Christ's Passion while simultaneously providing a specific commentary on current events or contemporary problems. I have participated in Fordon's Passion play three times: in 2008, 2009, and 2010. Each time a different script and a different message were presented.

Every year, the Easter performance in Bydgoszcz Fordon is watched by three thousand or more Catholic faithful from various regions of Poland (the majority of them from Bydgoszcz and the surrounding area). The audience is almost entirely comprised of Catholics, and most of them are pious Catholics who actively participate in Church and religious life. Fordon's Passion play's audience consists of people of all ages - from babies to the elderly, from oneyear-olds to those in their nineties. Many come to see the performance with their families, some with parish pilgrimages, and all, notwithstanding the distance traveled, whether it was three hundred kilometers or three hundred meters, view themselves and are viewed by the Passion Play organizers as "pilgrims".

The Easter play in Bydgoszcz was initiated by a group of friends who were and still are members of the parish in Nowy Fordon. All of those engaged in preparation of Fordon's Passion play are amateurs and have no professional experience in theatre or with performance realization. Performance organizers have learned how to present a play in the open air through practice, improving their skills through each performance. These organizers and performers desire to prepare a performance that, while it may be not on a professional level, is of a superior quality, and has been consciously elevated from an often naive and kitsch-ridden religious aesthetics which is present in some other religious amateur performances. Such is their play: suspended somewhere between aspirations to professional theatre and popular religious aesthetics. ${ }^{6}$ As David Morgan writes (referring to popular religious images, but the analogy is easily visible here): religious art cannot be simply judged as kitsch, since it above all responds to the needs of devout believers (Morgan 1999: 22-25). Passion play organizers, on the one hand, draw from high culture sources, incorporating into their performance fragments of poetry and drama, while on the other hand, they embrace a comparatively low artistic and intellectual level by introducing popular contemporary religious songs. They consciously renounce choosing one, particular aesthetical form of performance - professional drama or naive religious theatre - since such a choice could negatively influence or 
limit the audience's mode of experiencing the Passion play. Such a play must fit the faithful's expectations, allowing them deep religious experiences and involving them into the play. It cannot be too sophisticated or too simple, since religious beauty should be estimated not only in aesthetical categories: "We can therefore speak of beauty in visual piety as consisting neither in artistic skill nor in contemplative disinterestedness, but in reassuring harmony of believer's disposition toward the sacred with its visualization" (Morgan 1999: 33). This harmony is in Fordon gained by that conscious choice made by the play organizers: Easter performance cannot take on the form of professional theatre, the form often distant from and alien to ordinary people; at the same time it cannot be a naive religious play, because people expect it to be a stimulus to reflection, they want such a performance to be a serious, refined, but also attractive religious event. That is why Fordon's Passion play organizers pay a great deal of attention to the script of each performance, why they mix soundtracks from various sources (movies, computer games, symphonic overtures) to give the audience as touching music as possible. They use amateur but harmonious scene decorations, all designed and elaborated by a single man who has some carpenter skills but no artistic education. All costumes are sewn by a woman who is an amateur tailor; costumes for the Passion play are a kind of her opus magnum. Despite the amateur character of the play which is seen from the very first scene, performance organizers, probably thanks to their determination and hours of a voluntary work, achieve a remarkably high level of artistry. Their play is interesting not only because of religious reasons but also as a performance in the open air as such.

Perhaps there is one more factor which makes their work particularly effective: their commitment to the local parish and to the place where Easter play is presented. All Passion play organizers take active part in parish life. They make use of a Wiatrak (Windmill) Foundation that takes care of district inhabitants, of Fordon's regional promotion, and of local culture animation. The Windmill Foundation also cooperates with several parish groups: for students, singled men and women, married men and women, and so on. Most Passion plays organizers and actors are either closely or in some rare cases loosely attached to one of those groups. The foundation, apart from supporting Passion play organization, devotes its work particularly to the Nowy Fordon district since it is a quite poor area, with a high rate of unemployment, distant from the city centre, and somehow sleepy. It displays a typical post-socialist landscape: tightly built, unrenovated blocks of flats, with asphalt backyards and destroyed benches in front of them. There are almost no pubs, no restaurants, no cinemas, theatres, or other cultural institutions, in this section of a town inhabited by 36000 people. And among many initiatives undertaken by the 
Windmill Foundation to make Fordon more attractive for visitors and for its inhabitants is revitalization of the so-called Dolina Śmierci (the Death Valley) or Golgota XX wieku (Twentieth-century Golgotha). It is a park and a cemetery in one. In 1939 Nazis incarcerated here one thousand two hundred people in prevailing part intelligentsia from Bydgoszcz. They were all buried there without commemoration. Some of the bodies were exhumed, but around eight hundred were left there. It is the space where Fordon's Passion play is enacted. To understand the full message of the Fordon's Passion play, it is necessary to describe not only the history of performance, but also the history of the very place in which it takes place.

For years, Fordon's Death Valley was squalid and abandoned. Some giant sculptures of male figures were placed there, but they had nothing to do with the tragedy which took place in the Twentieth-century Golgotha. In the nineties, quite popular concerts of country music were organized in the Valley. It was a drunken, ill-behaved rout in the middle of a cemetery. Despite many protests concerning desecrating of a sacred place (a cemetery), the concerts continued for years, until a horrible event which definitively ended them. One year a young boy was knifed to death during a concert - yet another victim whose blood was shed in that place. His death contributed to the perception of the Death Valley as a place of martyrdom. This unfortunate event mobilized the local parish to act and transform the overgrown park into the Twentieth-century Golgotha, a place commemorating over one thousand victims of the Nazis, as well as the unfortunate death of the young concert attendee.

The general idea of parish members was to build Stations of the Way of the Cross there and to celebrate regular liturgical services during Lent and Easter. It took the parish several years to finish the construction of the Stations. When they were completed, the place became eternally connected with the martyrdom of Bydgoszcz's intelligentsia, while at the same time serving as a symbol of Christ's sacrifice. Passion plays performed in the Death Valley came to emphasize even more strongly the character of martyrdom and of sacred space bound in that place. It seems that the Twentieth-century Golgotha is an ideal space to present a Passion play. Not only the symbolic dimension, but also geological conditions make the Death Valley a good place for an Easter performance: the audience may stand on a small slope and observe events presented on an opposite slope, increasing audience comfort. However, although such factors contribute strongly to presentation of a Passion play, its history was, however, fraught with some difficulties.

The idea of presenting an Easter performance in Bydgoszcz Fordon came from one of the parishioners who participated in a Passion play performed in a sanctuary in Górka Klasztorna (which means Monastery Hill), a village not 
very far from Bydgoszcz. ${ }^{7}$ The play presented there is one of those performances mentioned in the beginning of the article which are based on the Way of the Cross script. Although the parishioner enjoyed being in this Passion play, he felt the lack of some deeper interpretation of Christ's Passion in it. Leaving behind his doubts if such a presentation of Christ's Passion was the most adequate one, he expressed his feelings to his friends, who were like him members of parish secular organizations, as well as a priest taking care of those organizations with an idea of organizing an Easter play in Fordon. Surprisingly, his fears that the presentation of only the scenes preceding Christ's death and resurrection might not be enough for a contemporary believer met with similar conviction from the local priest who declared that repeating the play from Górka Klasztorna would have no sense. The priest told his parishioners that they have to convince him by presenting an extraordinary project - a performance to which people would come and in which they would participate eagerly. Together with future Passion play organizers he came to the conclusion that despite the closeness of the Twentieth-century Golgotha, they could not only look back and propose that the audience reflect upon and brood over the past (both the execution of Bydgoszcz's inhabitants and Christ's death), but they had to give people an opportunity to reflect on their problems, on the problems of the surrounding world, and through this engage them into the Passion play. He delivered an ultimatum that a new script must be prepared every year and that the script should refer to events in the contemporary world and present Christ's Passion as a still actual and important source of everyday inspiration for the faithful. These central points and their consequent realization make Fordon's Passion play quite exceptional among Polish Passion plays. Having established the basic rules of the Passion plays' organization, and seeing in it an opportunity to revitalize the Death Valley and give this place a sacred (which here means also solemn) character, Fordon's parishioners begun their work.

Three Easter plays in which I participated had one common feature: they all had at least two main characters. One was Jesus, the other a personage who guided the audience through the performance. Each time the script of a play described Jesus' fate interwoven with the fate of another stage character. This "second" performance personage became a means to present the story of Christ in a contemporary context. The presence on stage of those "second" main characters allows Easter play organizers to actualize the meaning of Christ's Passion, introduce it into contemporary world, and confront it with contemporary problems. By doing so, Passion play organizers achieve an interesting artistic effect: their performance requires careful attention from audience members if they want to follow the action on stage, since it goes beyond the familiar 
script of the Way of the Cross. At the same time, this puts the whole event at risk. As Leo Howe and also Edward Schieffelin note, risk is inextricably written into performance (Howe 2000; Schieffelin 1996). They all (and in particular Howe) put the stress on the effectiveness of performance (Howe 2000: 76; see also Schieffelin 1996: 64), but with Fordon's Passion play the risk concerns viewer acknowledgement of the new interpretation of Christ's Passion when they are accustomed to its traditional presentation. By "traditional" I mean the presentations of the Passion rooted in Polish Catholic Church tradition for a long time, but also more recent depictions. In Poland, Mel Gibson's film The Passion of Christ is still very popular and very influential and is presented by many parishes and other religious organizations before Easter. For the Polish faithful, there is special meaning in the words ascribed (by legend, rather than authentic history) to "the Polish Pope", as John Paul II is called in Poland, when he purportedly said: "It [i.e. Gibson's depiction] is as it was" (Santana \& Erickson 2008: 91). The movie became a certain pattern for presenting Jesus' Passion - not only for the audiences of Easter performances, but also for the their organizers themselves, since directors and actors of many Polish Passion plays (which in many cases began long before the Polish premiere of The Passion of Christ in 2004), have declared to me that they would like their play to be as perfect as Gibson's film. Organizers of Fordon's Passion play, however, took the risk of breaking the pattern introduced by Gibson's Passion and also partially with the pattern derived from liturgical services. Although they admit that some singular scenes in their play were influenced by that movie (i.e. sorrow of Mary and Mary Magdalene after Christ's imprisonment), the whole performance is, in its structure (since the form is obviously different), dramatically different from Gibson's Passion.

\section{PASSION PLAY AD 2008: THE PROBLEM OF ENGAGEMENT}

The first Passion play in Fordon in which I participated presented the story of Mary Magdalene. Such a choice for second main character of the play had two reasons. Firstly the performance was directed by two women and they decided to make a woman the hero of their play. It is, however, not always the case that women directors choose women for the main character. One of the directors, also the author of a script, said that she wanted to underline the role of women in Christianity and that is why she decided to write a play about Mary Magdalene. She was even granted the nickname "M\&M", after the popular candy, making her a comfortable, familiar, and truly accessible character. Secondly, this choice was strongly influenced by media debate on the "revolutionary" content of the 
Da Vinci Code - a novel by Dan Brown. In Poland discussion of the bestseller involved many, including high Church authorities. ${ }^{8}$ Responses from the Catholic Church regarding the novel's suggestion that Mary Magdalene was betrothed of Christ were very harsh. Taking this into account, the directors of Fordon's play wanted to present the role of Mary Magdalene in the history of salvation in accordance with Catholic Church teaching and in the same time also to participate in a debate over popular religious "revelations", showing thereby that no new discoveries can compete with Gospels.

Mary Magdalene, however, was not only the main character of the play, not only a "defender" of traditional Church teaching, but she also was supposed to be a certain or "Everyman" with whom each Passion play participant, male or female, could identify. Usually in Polish religiosity, women identify primarily with saint women, especially with Mary (Bierca 2006; Kuźma 2008), while men only pray to them. With male saints and especially with Christ's apostles, men and women identify equally, although women often state that female saints are somehow closer to them. Presenting a male saint as a pattern of values and behavior for all the faithful is a much more common operation. To make a women a person "like each of us", as was said from the stage, was a unique and original idea (see Adamiak 1999).

And so in the first scene of performance we could see a girl named Anka (Ann) who remained in contemporary cloths said that she is going to show us a story which could happen to each of us. Then she took off her contemporary coat and revealed her scene costume as Mary Magdalene. After she had transformed herself into Mary Magdalene, the story of Christ's Passion began. It interwove ultimate scenes of Jesus' life with scenes of Mary Magdalene's conversion. The joint story of those two characters was shown not only as a story of Christ's Passion and Resurrection, but also as a story of a personal fall and Everyman's search for a personal way to God. Jesus' saving of Mary Magdalene from death, transforming her into one of His disciples so that she accompanied Him on His way to Golgotha and finally met Him after His Resurrection, became for the audience a particular mirror of their attitude towards God. She was sinful but through faith she managed to find the right path leading her to God. The message of the Fordon play was very optimistic - the viewers, the faithful, although erring and fallible, may also find their way to God, but they have to keep their faith as Mary Magdalene did.

Presenting the story of M\&M parallel to the story of Christ had above all one principal aim: to engage people into the performance, to make them reflect upon their religious attitude. To accomplish this, Passion play organizers decided to present a person involved emotionally in Jesus' Passion, since they wanted all members of the audience also to feel emotionally and personally involved 
in the Passion. Organizers of the play focused a great deal of effort in making it possible for the faithful to feel as if they were witnessing Christ's Passion.

The idea of "transferring" the faithful into ancient times when these events took place and of experiencing through Passion plays Christ's Passion in the same way as it could have been experienced by the faithful over two thousand years ago is simultaneously an aim of the Passion plays organizers, and a true experience of some viewers of Easter performances. The organizers in Fordon want their audience to experience "something deeper", to get involved in the action of a scene, to make them feel as if they were a part of the crowd which accompanied Christ in the Way of the Cross. To achieve their goal they not only introduce personages with whom a viewer may identify, they also try to engage people into performance in another way. When Christ shares bread with the Apostles, loaves of bread are distributed among the audience so that they feel as if they are somehow participating in the Last Supper. To make the audience more involved in the performance, in Fordon organizers decided to lead the Way of the Cross not through a separated area such as the stage, but

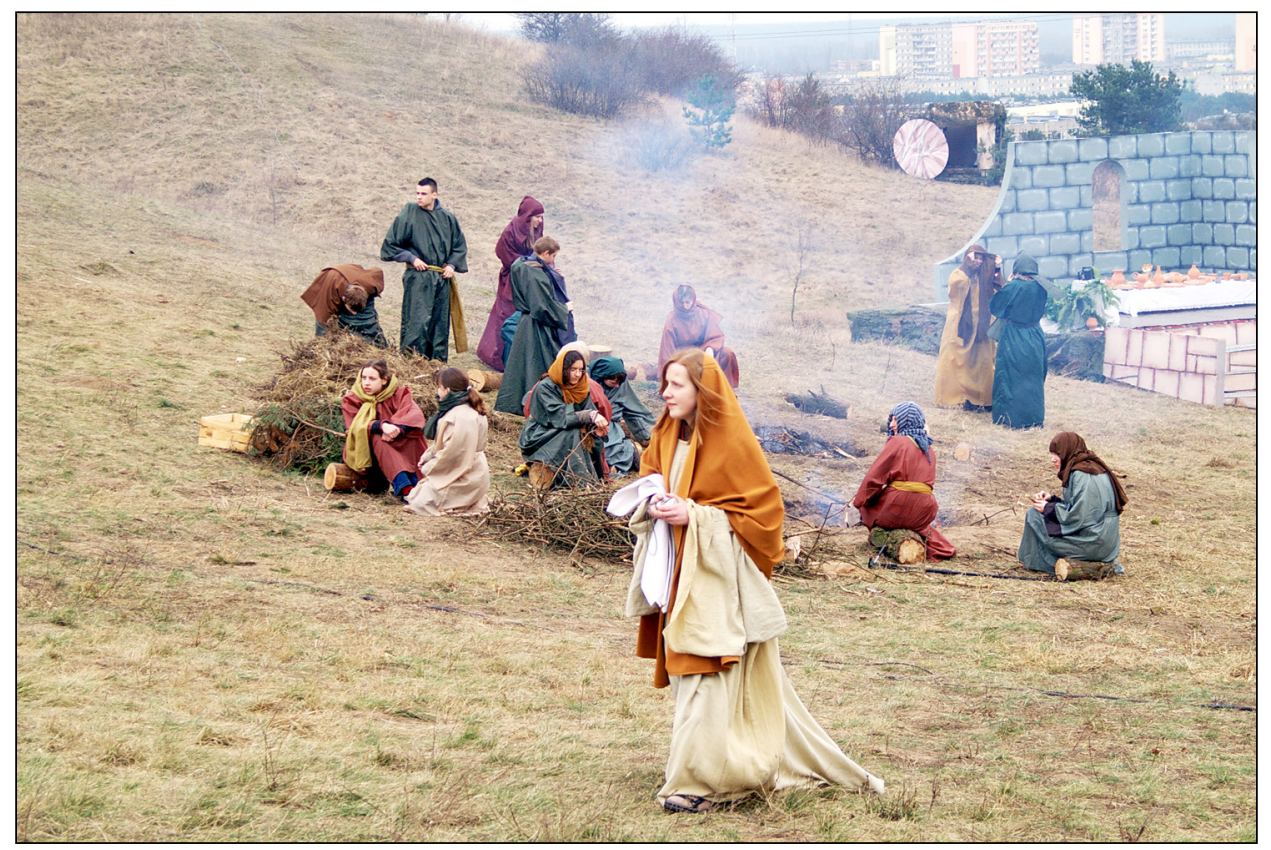

Figure 1. Jerusalem enacted in Passion play, Bydgoszcz Fordon, 2008. Photo by Pawet Baraniecki. 
through the audience itself. Persons playing Roman soldiers were told to pave the way through the audience, and even to push (gently) or shout at members of the audience to make more room. Further, the Simon of Cyrene character is taken from the audience to help Christ carrying the cross. Usually this person knows he will be chosen to do it, but he wears contemporary cloths and looks like one of the audience members and not one of the actors, which increases the impression that he really is "one of us" - one of the viewers.

Passion play organizers make their every effort to prepare a performance that will strongly influence the audience. And they often succeed. Engagement of the faithful into the play causes them to feel as if they experienced Christ's Passion as if they were there on Golgotha. Such experiences are not shared by everyone, but are common and were described to me by many Fordon Passion play viewers in a subjunctive mood. Such a mode was strongly ascribed by Victor Turner to liminal and religious experiences (see Turner 1982; 2002). The idea that through the Easter play they felt as if they were in Jerusalem expressed precisely the wishfulness and potentiality present in the liminal

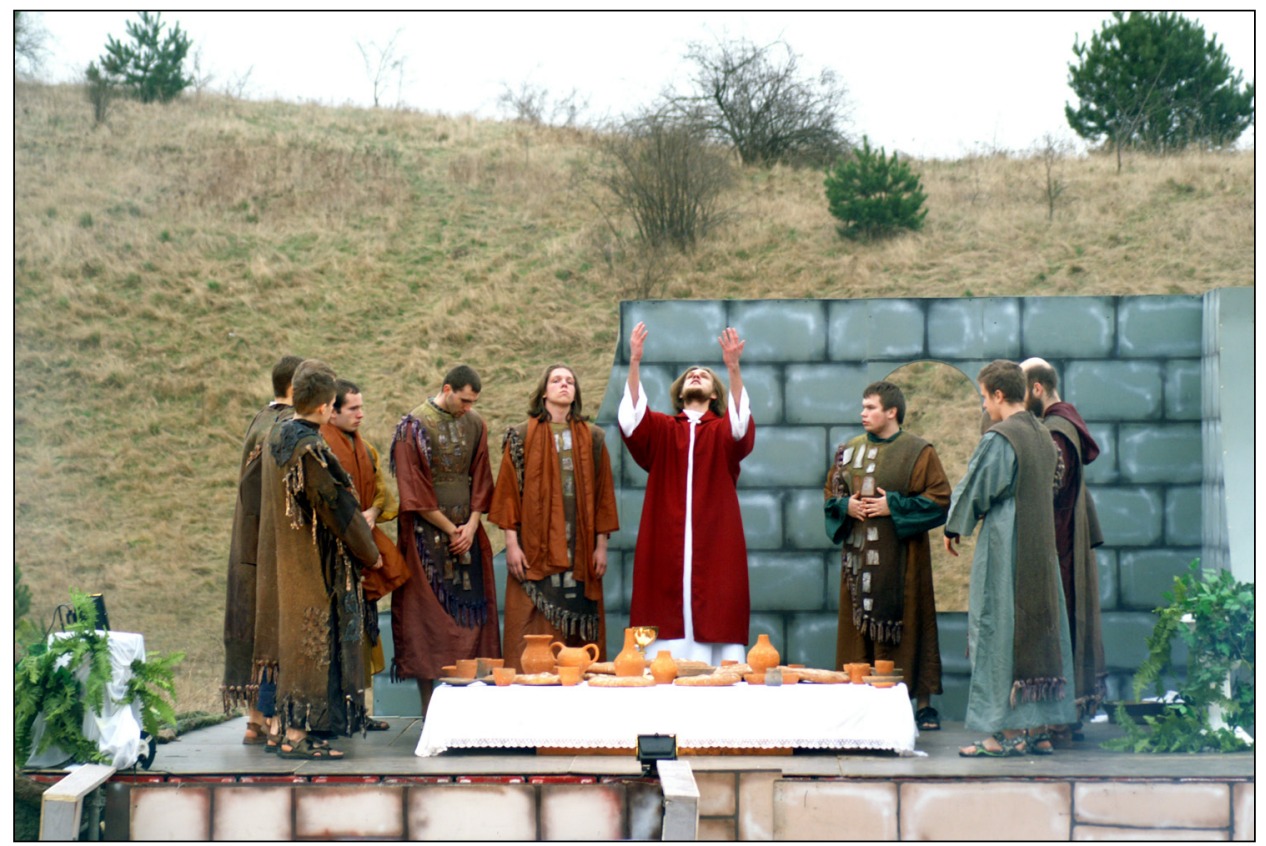

Figure 2. Last Supper, Bydgoszcz Fordon, 2008, photo by Pawet Baraniecki. 


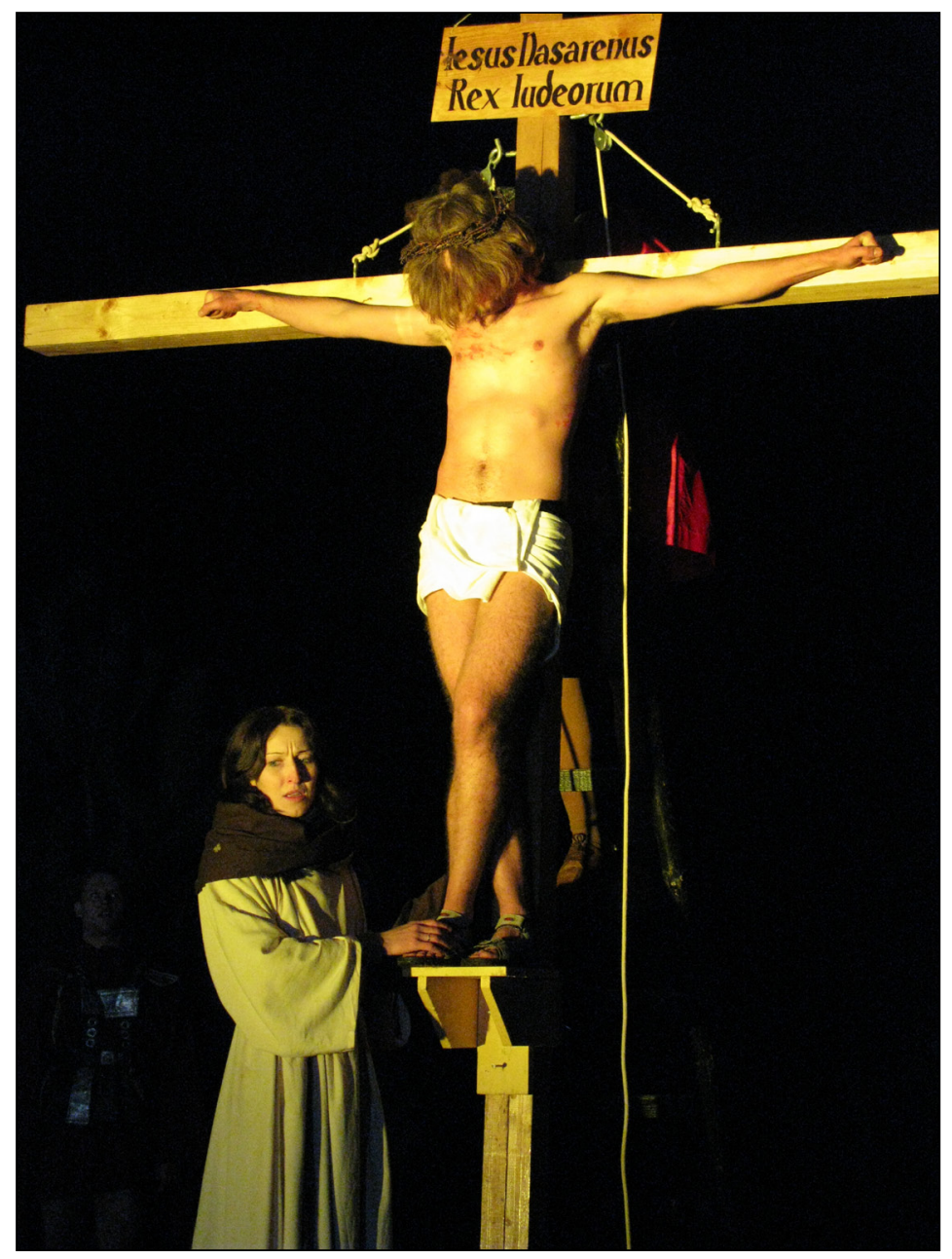

Figure 3. Mary Magdalene mourning Christ, Bydgoszcz Fordon, 2008, photo by Mikołaj Olszewski.

and in the same time allowed the faithful the opportunity for deep religious experiences. The faithful participating in Passion plays are, of course, aware that they are watching only a represented story, but they experience it as if they were watching the real Passion of Christ. And it is precisely this that both the Passion play organizers and their audience members consider the crowning achievement of the performance. 


\section{PASSION PLAY AD 2009: THE RISK}

Not all performances in Fordon, however, are developed primarily to engage viewers emotionally. Some are developed to involve them intellectually as well, to make the audience consciously think about what is going on the stage, consciously following the action of performance. The second play in which I participated had the most sophisticated Easter play script I have ever heard of; however, the performance, because of the complicated plot, was a very high risk for failure. The script was written by a married couple who had worked in Fordon's Passion play organization for several years. They chose Saul/St Paul for the "second" main character. Such a choice might seem obvious since 2009, the year of that performance, was announced by Vatican to be the year of St Paul. The idea of the script writers, however, was not that trivial. They were looking for a personage who could be confronted with Christ as an opposite thinker, someone for whom the teachings of Christ seem unacceptable, but who finally converts to Christianity. They found such a person in Saul. The concept of the play did not assume, however, the simple presentation of a pious Jew who

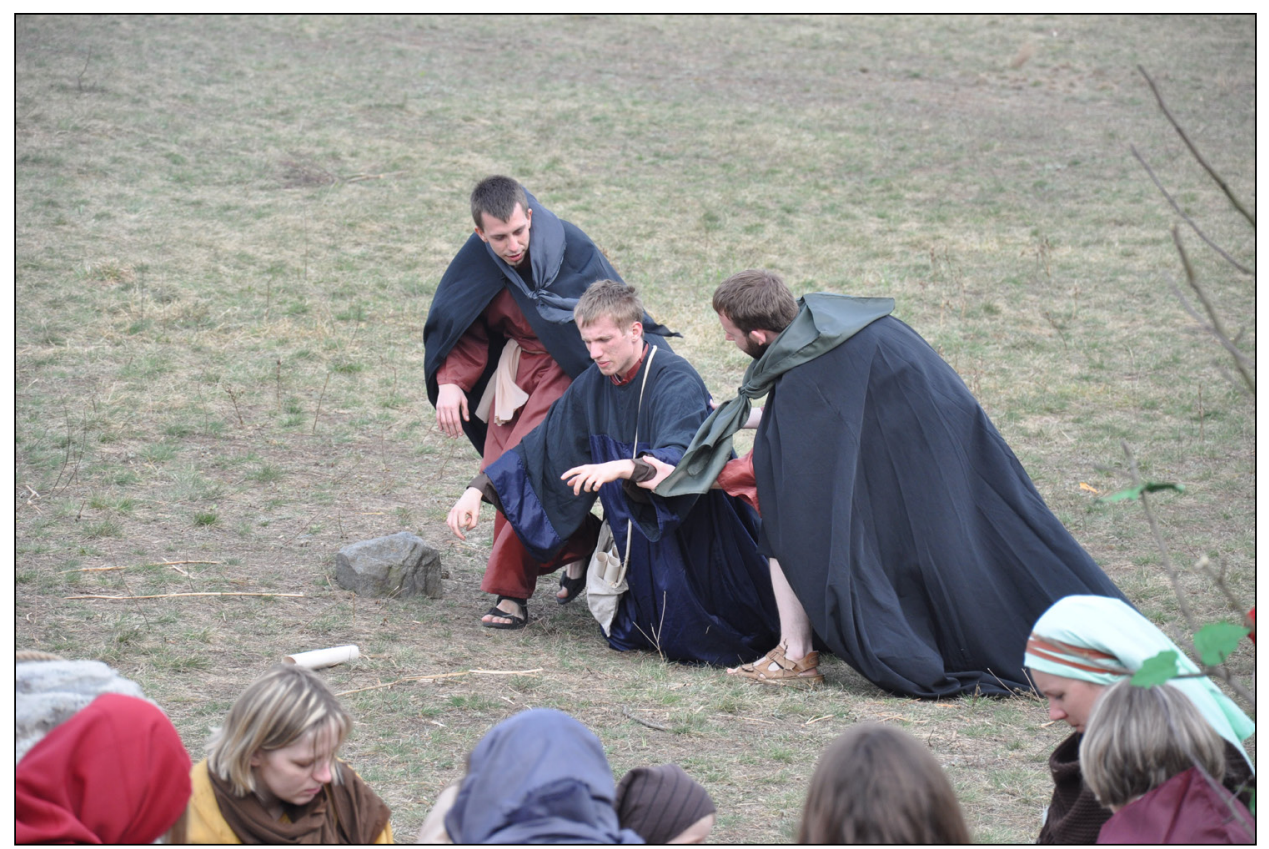

Figure 4. Saul losing sight on his way to Damascus, Bydgoszcz Fordon, 2009. Photo by Pawet Baraniecki. 


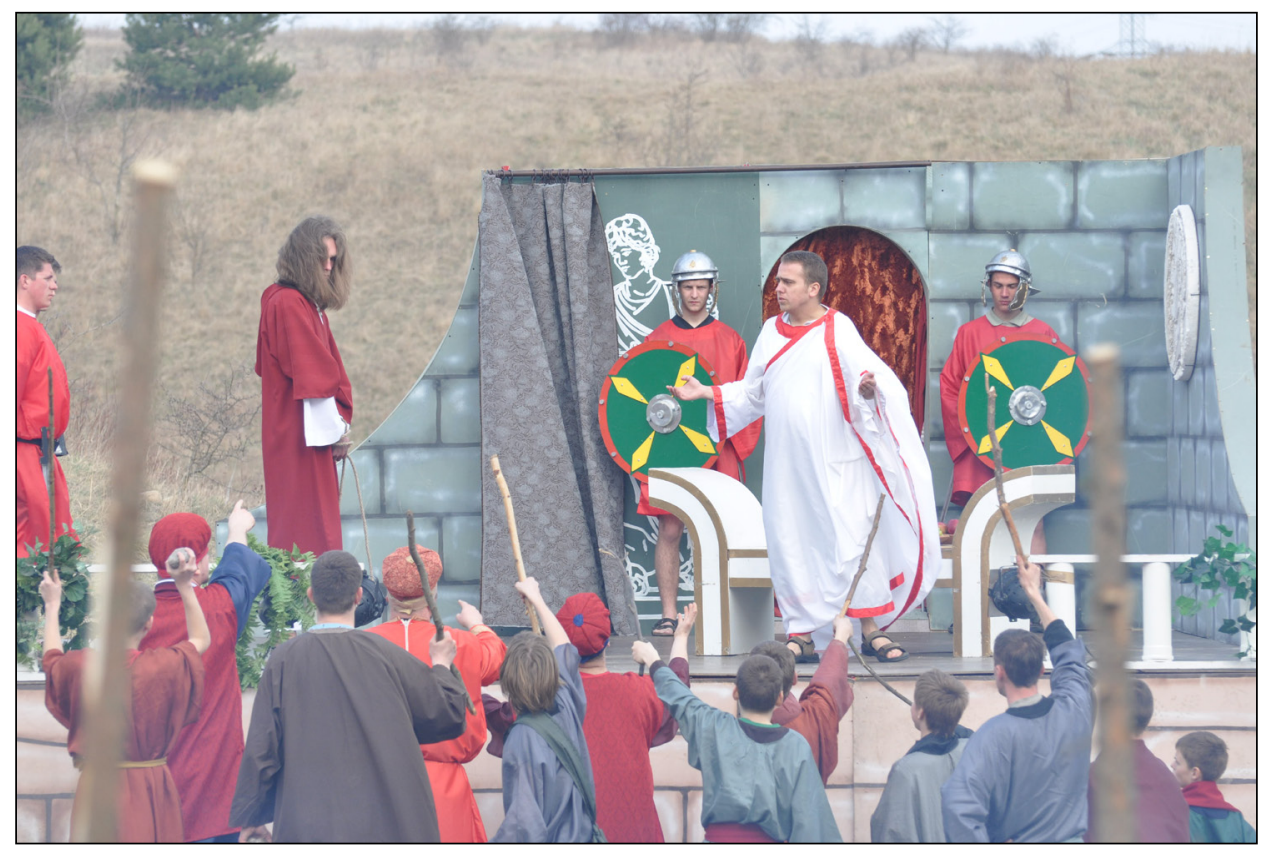

Figure 5. Christ before Pilatus, Bydgoszcz Fordon, 2009. Photo by Pawet Baraniecki.

converts to Christianity. Script writers wanted to show how similar thoughts, similar intensity of faith, may lead to opposite conclusions - to right (from the Catholic perspective) in the case of Jesus, and (initially) to wrong (again from the Catholic perspective) in the case of Saul.

To gain this goal the Easter play presented, among other scenes from Christ's Passion and Saul's life, parallel and comparable scenes from Saul's and Christ's life. I will enumerate only those scenes which were introduced by the script authors to underline ties or radical differences between the lives of Jesus and Saul. The whole performance began with the journey of Saul to Damascus when he is blinded by lightning and he hears the voice asking him "Saul, Saul, why persecutest thou me?" (Acts 9: 4). Later on, blinded and desperate, Saul refuses to eat supper in his room in Damascus; simultaneously, a scene plays out next to this wherein Jesus eats the Last Supper with His apostles. Then Saul despairs that everyone will deny him since he is blind; at the same time St Peter talks with Christ "Although all shall be offended, yet will not I. And Jesus saith unto him, verily I say unto thee, that this day, even in this night, before the cock crow twice, thou shalt deny me thrice. But he spake the more vehemently, If I 
should die with thee, I will not deny thee in any wise. Likewise also said they all" (Mark 14: 29-31). In the next scene both Saul and Jesus start to pray-Saul in his room and Jesus in Gethsemane. When Saul asks God to take away this cup from him, his words conclude with Jesus' in His prayer (Mark 14: 36). When Jesus is captured and taken to Pilate, Saul is sleeping and in his dream he constantly hears the question "Saul, Saul, why persecutest thou me?" (Acts 9: 4). The crucifixion is in process at the same time Saul prays to God to help him in his hopeless situation. Both Jesus and Saul in the same moment speak: "My God, my God, why hast thou forsaken me?" (Mathew 27: 46). When apostles carry the body of Christ to the tomb, Saul converts to Christianity and regains his sight. The resurrected Jesus meets with his disciples and when he says to Thomas "blessed are they that have not seen, and yet have believed" (John 20: 29), Saul, baptized as Paul, confesses his faith. The whole performance ended with a scene in which Paul sits down to write his first Letter to Thessalonians. Small pieces of paper with a fragment of this Letter - "Quench not the Spirit. Despise not prophesyings. Prove all things; hold fast that which is good" (1 Thess 5: 19-21) - were distributed among the audience. After this conclusion, Paul, along with Christ and other actors, moved towards the audience.

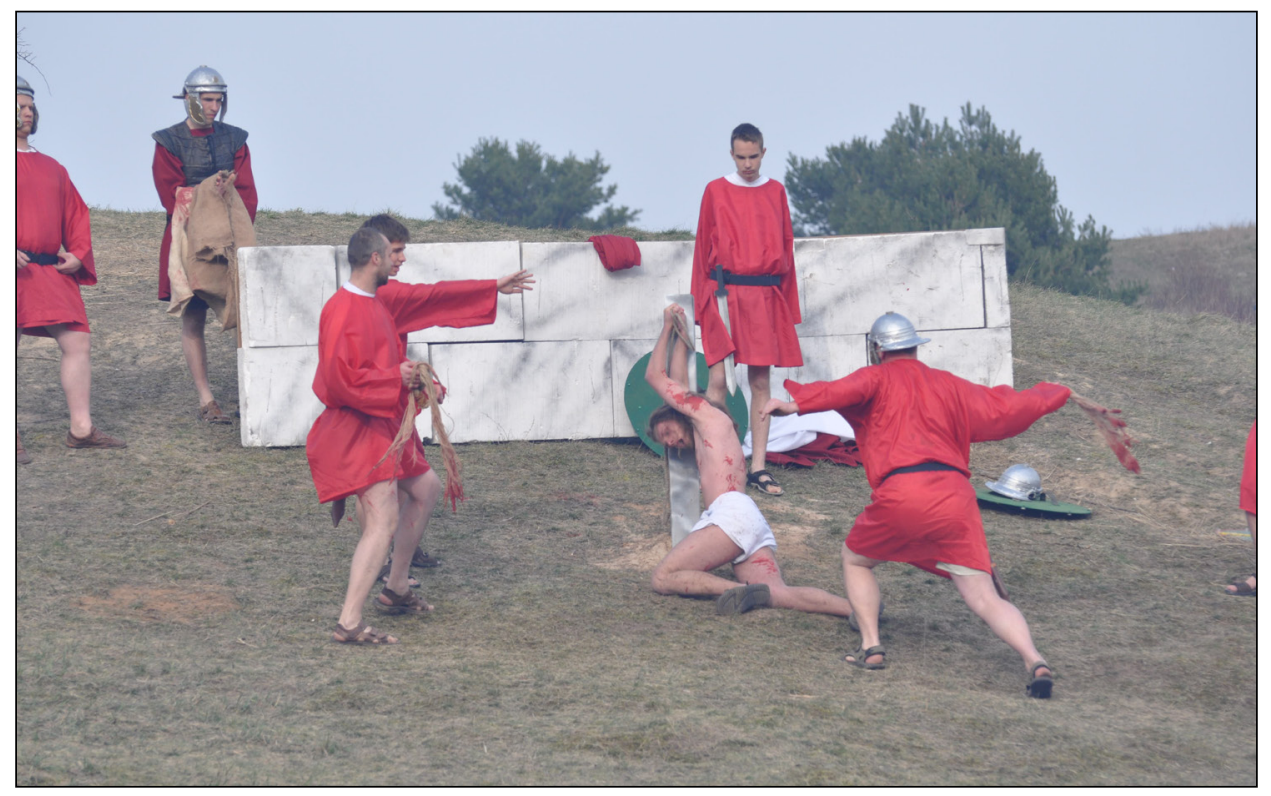

Figure 6. Flagellation, Bydgoszcz Fordon, 2009, photo by Pawet Baraniecki. 
The audience watched the 2009 performance with careful attention and its members seemed to be very focused on what they were experiencing. However, I still have some doubts whether it was because of a well-known root paradigm of the Way of the Cross, especially important in Polish Catholicism, or if it was the sophisticated script that moved the audience to deeper reflection.

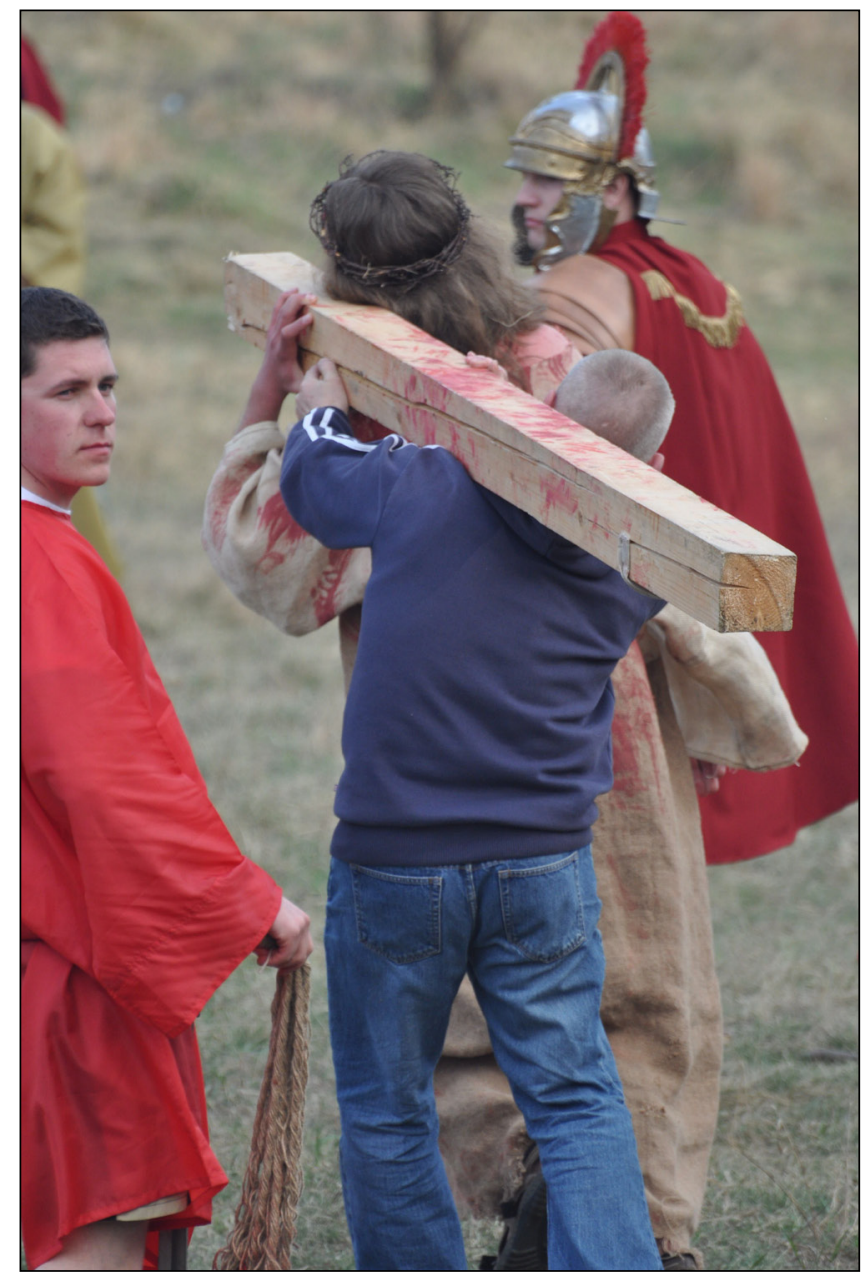

Figure 7. Simon of Cyrene, Bydgoszcz Fordon, 2009, photo by Pawet Baraniecki. 


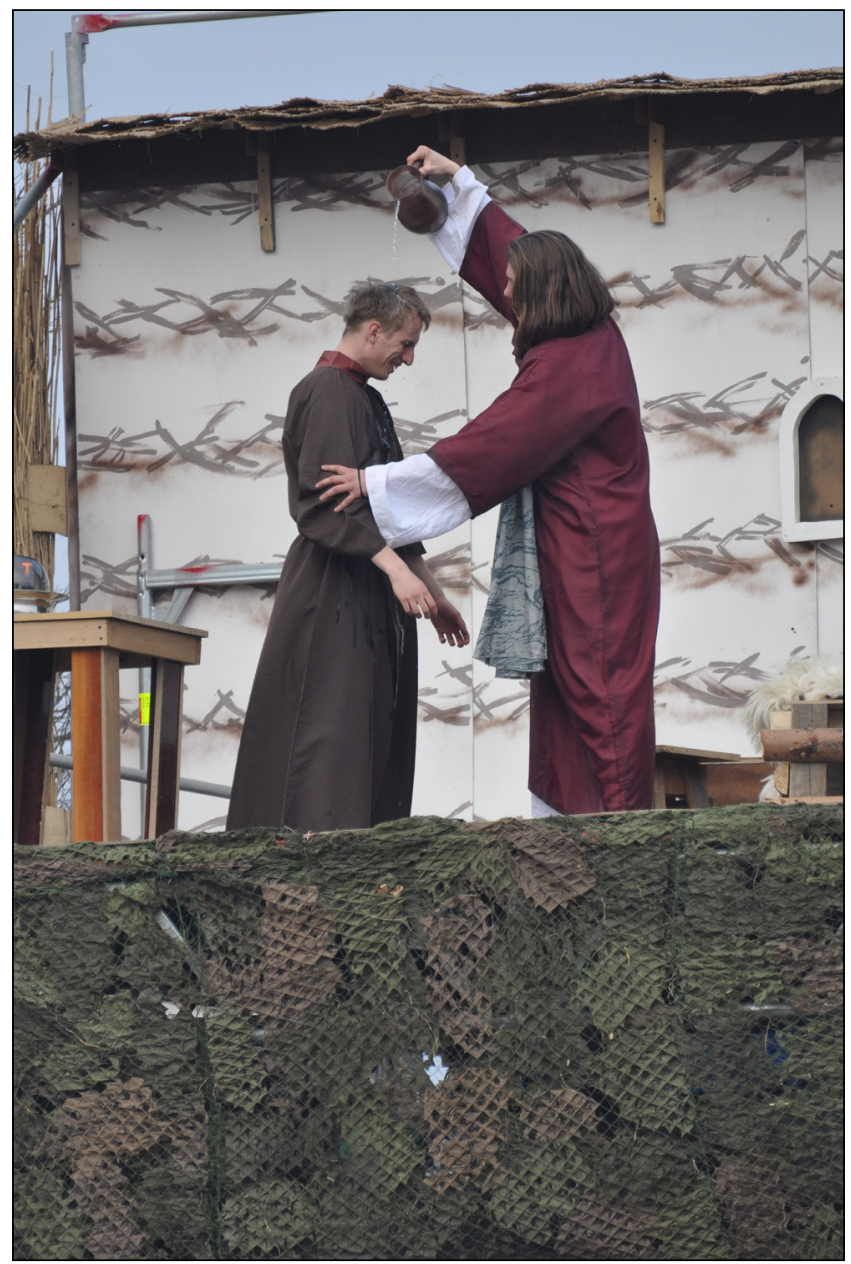

Figure 8. Saul's / Paul's baptism, Bydgoszcz Fordon, 2009, photo by Pawet Baraniecki.

I must confess that I would not understand the main idea of this particular Easter play if I have not discussed it earlier with the author of the script. Thanks to my conversations with him, I tried to follow all of the parallels between Christ's and Saul's histories to grasp the message of the performance. My doubts are also increased by the fact that I have not heard any play viewer state that they have identified with the personage of Saul/Paul, even though he was represented as "one of us" - a person who seeks God but does it in a wrongful way until the moment when this person converts and believes rightfully. 
I cannot state, however, that this performance was a failure in a sense described by Howe or Schieffelin (Howe 2000; Schieffelin 1996). The faithful who gathered in the Death Valley experienced it truly and this event helped them to prepare themselves for Easter. The play answered their expectations, though not all of them could grasp the main message which was not revealed on leaflets or on the web site. But they without a doubt understood and internalized the message which was inscribed into the Passion of Christ and its interpretation in the Catholic Church. The root paradigm of the Way of the Cross worked so successfully in that case that it covered everything that was lacking in acknowledgement of the performance as successful. Passion play organizers in Fordon farsightedly did not change the traditional and popular version of Christ's Passion itself. They innovated only the histories of few personages, suggesting their own interpretation of the Passion as additional to and not in contradiction of the official Church position. This saved the Easter play from the risk of failure and simultaneously gave the organizers opportunity to present their insight regarding their contemporary understanding of Christ's Passion.

\section{PASSION PLAY AD 2010: THE PROBLEM OF COMMENTING REALITY}

The last performance I saw in Bydgoszcz Fordon was also designed in reaction to the Vatican's announcement establishing 2010 as a year of the priesthood. Passion play organizers decided to attract the audience's attention to the personage of a priest who loses his faith but finally turns towards God. This time the aim of the Easter play organizers was not to present a person with whom everyone could identify, but to show a priest as a person of flesh and blood, capable of errors and often sinful, although constantly trying to strengthen his faith. In Poland at the time, there was a great deal of media attention focused on priest misconduct, shameful behaviors and acts which discredited them in the eyes of public opinion. Fordon's Passion play showed a man torn in doubt, losing faith, but finally regaining it. It was a way to have a say in a current discussion and to point out that not all erring priests behave shamefully, and are not all the evil, shameless, and cynical men as portrayed by certain members of the media. Some priests err simply because that is human. Fordon's Easter performance showed a priest as an ordinary human being, not a saint, but one who in spite of his imperfections, makes the effort to be better.

The impulse which, in the performance, turned the priest on the right path was a book by Roman Brandstaetter, Jezus $z$ Nazarethu (Jesus of Nazareth). ${ }^{9}$ The priest on the main stage read some fragments of it during the performance, 
while scenes described in it were represented on neighboring stages - namely those from the Passion of Christ. The priest regained his faith through reading a fragment about Jesus' crucifixion. When Christ resurrected, "resurrected" also the priest's faith and joy in doing service to others. In the final scene both Jesus and the priest blessed viewers gathered for the performance.

From the three performances I have seen in Bydgoszcz Fordon the last one in the most direct way presented the stand of the Catholic Church regarding a contemporary social problem (earlier, as in 2009, it presented a firm theological stand, such as in the case of Mary Magdalene's role in the history of salvation). There was (and still is) increasing pressure on the Church to solve internal problems; these are manifested principally, at least in the media, in distrust towards priest. The Catholic Church in Poland consequently defended and defends its clergy; the 2010 Passion play could be read as a part of such defense. Usually, however, Fordon's Easter play organizers left more space to the audience members for their individual reflection and judgment on contemporary social issues. The performance about the doubting priest was not the first one

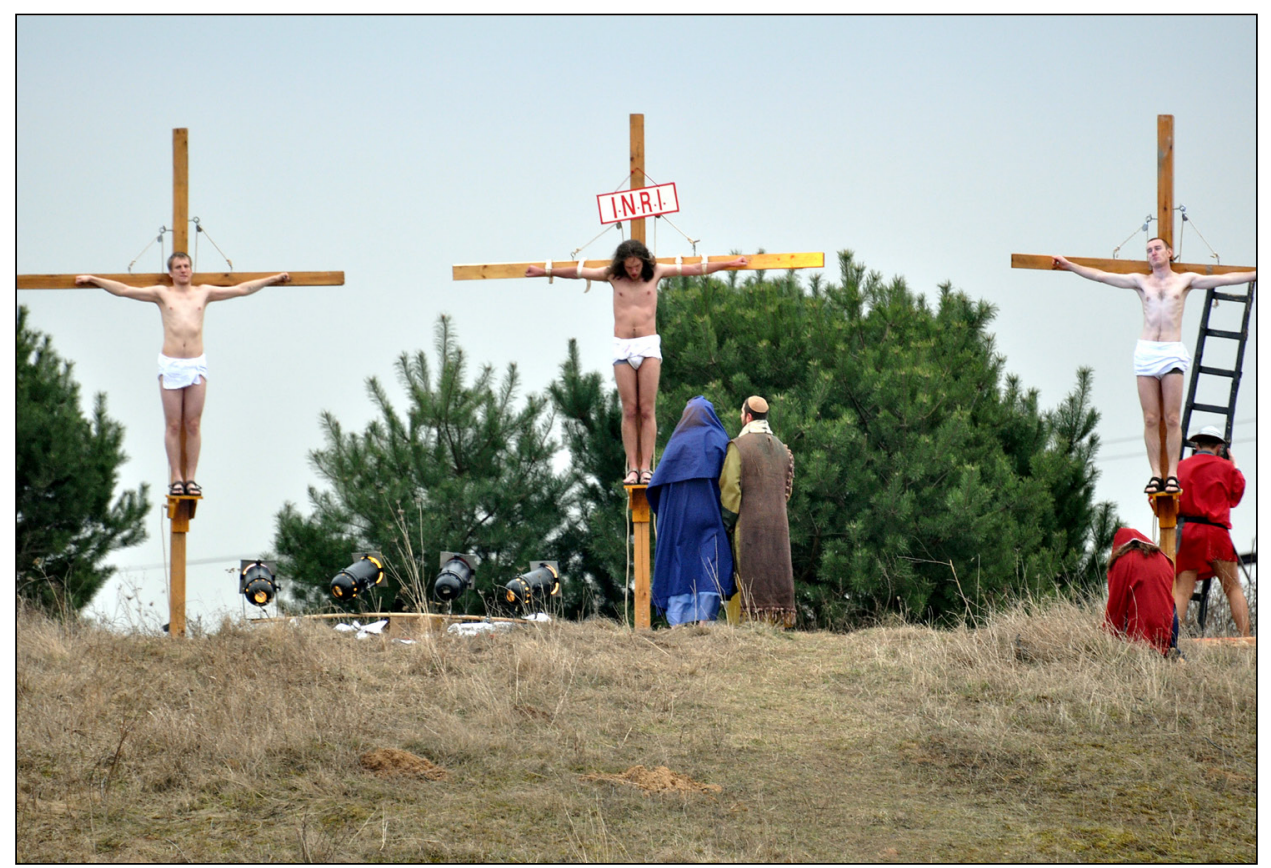

Figure 9. Crucifixion, Bydgoszcz Fordon, 2010, photo by Pawet Baraniecki. 
touching actual social or even political problems in Poland. In 2004 when an idea of vetting ${ }^{10}$ of the politicians was reappearing in Poland, the Fordon Passion play dealt with the notion of betrayal. There were two additional main personages, aside from Christ: St Peter and Judas, two traitors, one on whom was eventually saved and one of whom was forever condemned. The problem of betrayal was discussed in media at that time and particular political parties were trying to gain popularity through their attitude towards Communism and the necessity of settling accounts with it. In broadcast media, however, the conviction prevailed that any kind of collaboration with the Communist government - so-called denouncing and cooperation with the political police was a betrayal. In the Passion play, two traitors were shown and two possible endings and consequences of treason occurred. Judas became a universal symbol of a traitor and St Peter, despite his original denial of Jesus, became one of His closest disciples. And the viewers of the performance, although it obviously referred to the vetting problem, were left to judge the weight of it themselves.

In 2006, an Easter play also referred to the current problem of a labor migration of Polish youths to other countries of the European Union. After

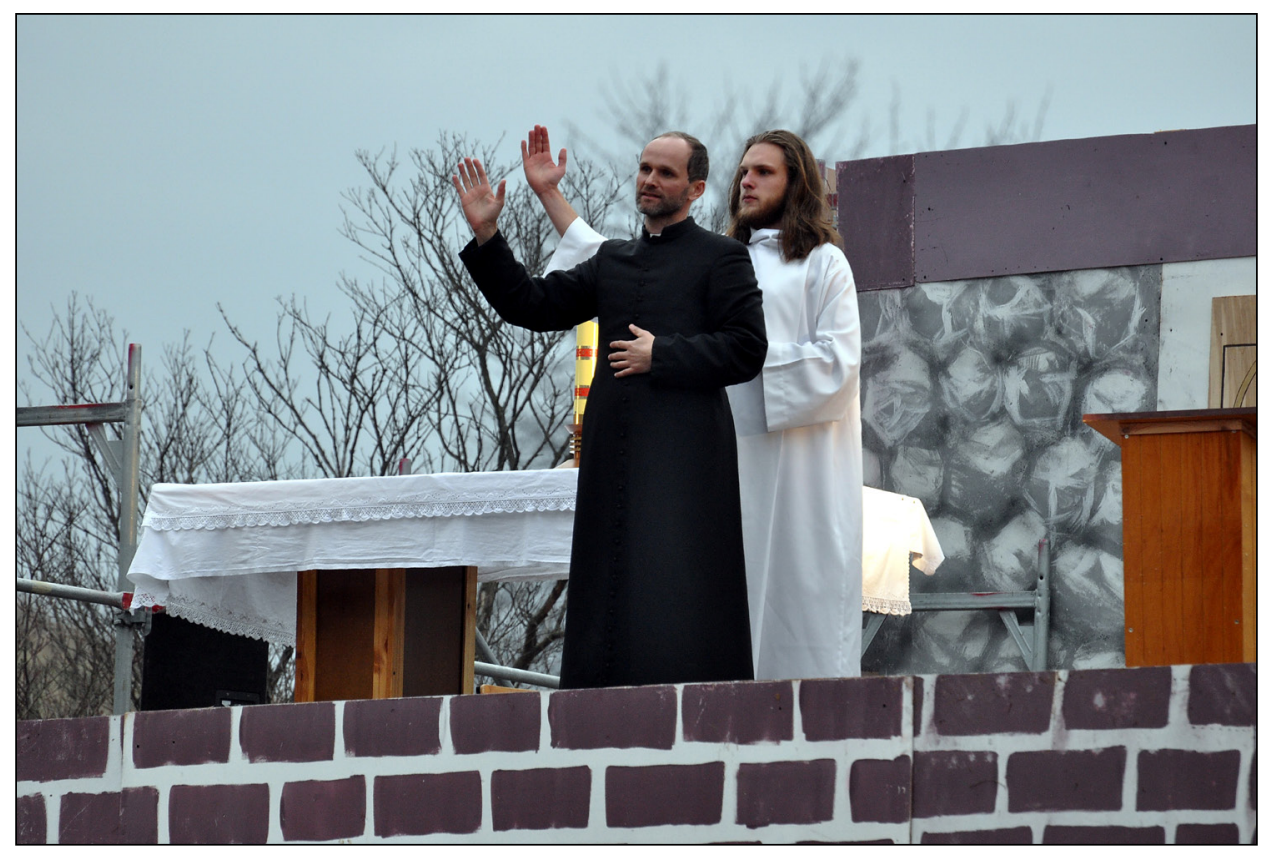

Figure 10. Christ's and Priest's blessing, Bydgoszcz Fordon, 2010, photo by Paweł Baraniecki 
joining the EU, work possibilities for Polish citizens increased significantly and many people, especially young ones who saw no real opportunities in their home country, decided to look abroad. The process was a mass one and, as in such cases, was not successful for all migrants. Many returned to Poland with disappointed expectations or stayed in foreign countries in badly paid jobs or working there illegally. The Passion play showed a story of such a migration, also leaving the audience the possibility to work out their own judgment on this social phenomenon.

Notwithstanding leaving the audience the possibility of finding an answer to the presented problem or giving it a ready answer, Fordon's Easter play often raises contemporary issues and in a quite exceptional way actualizes the meaning of Christ's Passion. Only a few organizers of Passion plays in Poland incorporate commentary regarding contemporary issues into the script and, from those plays personally known to me, only those from Bydgoszcz Fordon do it to significant effect and grant contemporary social or political issues that much space in the script.

\section{CONCLUDING REMARKS}

Such actualization of the Passion of Christ inscribed in an Easter play is particularly important for the faithful. They expect religion to be linked to the present and they also often seek in religion answers for dealing with living in the contemporary world. Fordon's Passion play shows them how religious content may be used in a reflection on contemporary problems. Here we can refer to a process which Edward Schieffelin described as the cultural construction of reality (Schieffelin 1985: 721-722). He pointed out how healing performances being also as a kind of religious rituals may result in transferring some meanings or symbols into social life "after" the performance. Also, participation in Passion plays results in transferring meanings into ongoing daily life - meanings which are sought by the faithful, as they themselves declare. Believers often find in such plays some personal instructions how to act or how not to act. That is why referring the history of Christ to contemporary issues as presented in Fordon fits their religious sensitivity so well. Evoking such meanings is the first kind of Passion plays efficacy. Passion play organizers, as I mentioned earlier, want their performances to give the faithful answers to the problems of contemporary world; they want it to be meaningful and they achieve this goal. Moreover, they realize it through the second kind of efficacy - encouraging people to reflection.

Fordon's performance, as I mentioned, does not only repeat the scheme of the Way of the Cross; this root paradigm is present anyway in almost every 
religious service of Lent and Easter time. It exceeds it, giving the faithful an opportunity not only to recall and reflect upon the Passion of Christ, but also to refer it to contemporary issues, contemporary problems. Fordon's Passion play invites audience members to reflection and, as many of them admit, does so in a much more successful and persuasive way than regular liturgy. And in this way the Passion play makes experiencing Easter deeper. Deep and conscious experience of the religious reality becomes a crucial expectation of the contemporary faithful who want to develop in their religious life and often seek additional occasions for their spiritual growth apart from liturgy. ${ }^{11}$ They attend Holy Mass and liturgical services, but they need also an additional impulse to feel a kind of religious fulfillment. Passion plays give them one.

The last-described kind of efficacy is the most concrete; it brings particular, visible outcomes, but is limited to those participants of the Passion play who live in Bydgoszcz, especially in Nowy Fordon. The Passion play is not only the biggest religious event of the district, but also the biggest cultural event. It is a particular feast in Nowy Fordon, although no commercial event accompanies it. In this aspect Passion plays are quite exceptional religious events in Poland, since there are no market stalls with devotional art, sweets, toys, or fast foods, which are present at all patronal Saint feasts and other major Catholic religious celebrations. In Fordon one can only buy (through voluntary donation) a piece of cake made by parishioners or drink a cup of tea, and all donations raised in that way are allotted to Passion play purposes. Nonetheless, for Fordon inhabitants the Passion play is a great event. After a solemn Holy Mass and the blessing of Palm Sunday palms at church, they go to the performance presented in a place particularly important for all people living in Bydgoszcz. The Death Valley is a place marking their identity, reminding them of their particular past: before World War II Bydgoszcz was a multicultural city inhabited by Germans, Jews, and Poles. This epoch was completely erased by the Nazis.

The presentation of Fordon's Passion play, i.e. the martyrdom of Christ, in a place of the martyrdom of Bydgoszcz inhabitants revives history-a history that is still fresh for many inhabitants today. ${ }^{12}$ Some Easter performance viewers lost their relatives or friends in the Death Valley; some have learned about it at school or heard the story from their neighbors. Through the presentation of the Passion of Christ on this Twentieth-century Golgotha, personal identification with the place and its story increases.

Fordon's Passion play gives meaning to the religious story, to local identity and local history, and to contemporary social or political problems. And it is exactly how it constructs reality of the faithful, especially of those living in Nowy Fordon. All these aspects of efficacy do not cover completely the meaning of performativity introduced by Tambiah (1985). The purpose of the Passion play 
is also not as clear as in some rituals. Their performative potential produces effects dependent on the historical, cultural, and social context. They are to some degree contingent, since they depend mostly on the faithful's reception of performance (unlike in the other examples of performativity presented at the beginning). In this sense the effect is not inscribed in the nature of Passion plays. Efficacy here deals more with potentiality to do and perform something; it is a performativity with an open ending, based on convention more loosely than Tambiah stated. The convention in the case of the Passion play provides a spectrum of possible effects, in contrast to the Austinian understanding when one particular action gives one particular effect. Thus efficacy described here could be also called effectiveness of performance; however, it constitutes an indispensable part of considerations of efficacy perceived through performativity.

\section{ACKNOWLEDGEMENTS}

The author is a holder of a scholarship Start 2013 of Polish Foundation of Science. The research was funded by a grant of Polish Ministry of Science and Higher Education no N N109 224536.

\section{NOTES}

1 Various notions of this category are in detail described by Podemann Sørensen (2006).

2 We have to remember that often rituals are interpreted in terms of performance theory and thus gain a name of performances (see Schieffelin 1998).

3 On changes in Polish Catholicism after the fall of Communism see Borowik (2003).

${ }^{4}$ I mean here Passion plays which follow a traditional script and do not exceed it. Usually they are deeply rooted in Church tradition as well as in popular religiosity. As an example here may serve Italian (see Gisolfi d'Aponte 1974) or Mexican (see Trexler 2003) Easter plays.

5 Fordon is a district of Bydgoszcz - a city in North-Central Poland. Its full name is Nowy Fordon (which means New Fordon) since Stary Fordon (Old Fordon) is another district, previously a separate town, later included along with Bydgoszcz in its district. For the organizers of the Passion play relation with their district, far from the city centre (not spatially, but mentally) is very important and they themselves align their Passion with Fordon's.

6 On this particular kind of aesthetics of amateur performances see Gapps on historical reenactment (2002: 68-69). 
7 The Passion play in Górka Klasztorna had been recently a subject of anthropological research on changes in a model of popular religiosity; however, it is still presented as a traditional kind of religious performance (see Eichstaedt 1998; Kunczyńska-Iracka 1988).

8 See e.g. Jankowska 2008: 141-142. Such responses to Da Vinci Code were quite common, however (see de Groot 2009: 53-54).

9 Roman Brandstaetter was a Polish poet and writer. He was born in a Jewish family in 1906, and during World War II, while living in Jerusalem, he converted to Catholicism. Most of his works deal with religious topics. Jesus of Nazareth is one of his greatest and best known works.

10 The idea of vetting, understood here as a necessity of limiting the presence of former communists and above all people cooperating with communist political police on civil service positions, was introduced before 2006 (the first vetting bill was voted by the Parliament in 1992). However, in 2006, to put it briefly, vetting became a political tool of rightist parties in Poland and a discussion on its validity was raised in the media.

${ }^{11}$ Some find it e.g. in so called New Religious Movements within Catholic Church.

12 To some degree an analogical situation exists in Poznań (Pozen), a city in centralwestern Poland where the Passion play is represented on a citadel in the middle of the city, called Pozen's Golgotha because of many victims of two World Wars buried there.

\section{REFERENCES}

Adamiak, Elżbieta 1999. Milcząca obecność. O roli kobiety w Kościele. [The Silent Presence. The Role of Women in the Church.] Warszawa: Więź.

Bierca, Marta 2006. Mistyka typu ludowego. Kobieca pobożność maryjna w świetle teologii feministycznej. [Folk Mysticism. Women's Devotion to Mary in the Light of Feminist Theology.] In: K. Leszczyńska \& A. Kościańska (eds.) Kobiety i Religie. Kraków: Nomos, pp. 119-138.

Borowik, Irena 2003. Transformations of Catholicism and Religiosity of Catholics in Poland. In: I. Borowik (ed.) Religions, Churches and the Scientific Studies of Religion: Poland and Ukraine. Kraków: Nomos, pp. 41-59.

Eichstaedt, Jarosław 1998. Być w Górce Klasztornej i pamiętać Kalwarię. [To be in Górka Klasztorna and remember Calvary.] Lud, Vol. 82, pp. 47-59.

Gapps, Sthephen 2002. Performing the Past: a Cultural History of Historical Reenactments. Ph.D. thesis, Sydney: University of Technology.

Gilosfi d'Aponte, Mimi 1974. A Passion Play near Amalfi. The Drama Review. TDR, Vol. 4, pp. 47-55.

de Groot, Jerome 2009. Consuming History. Historians and Heritage in Contemporary Popular Culture. London-New York: Routledge.

Howe, Leo 2000. Risk, Ritual and Performance. The Journal of the Royal Anthropological Institute, Vol. 6, No. 1, pp. 63-79. 
Jankowska, Magdalena 2008. Sacrum w epoce rozrywki. Apokryficzność jako forma religijności współczesnej. [The Sacred in the Era of Entertainment. Apocryphality as a Form of Contemporary Religiosity.] In: W. Muszyński \& M. Sokołowski (eds.). Homo creator czy homo ludens. Toruń: Wydawnictwo Adam Marszałek, pp. 136-143.

Kunczyńska-Iracka, Anna 1988. Misterium Męki Pańskiej w Górce Klasztornej. [The Passion of Christ in Górce Klasztornej]. Polska Sztuka Ludowa, Vol. 42, No. 1-2, pp. 93-101.

Kuźma, Inga 2008. Współczesna religijność kobiet. Antropologia doświadczenia. [Religious Women Today. Anthropological Study.] Wrocław: PTL.

Lambek, M. (ed.) 2002. A Reader in the Anthropology of Religion. UK: Blackwell Publishing.

Morgan, David 1999. Visual Piety. A history and Theory of popular religious images. Berkely \& Los Angeles \& London: University of California Press.

Podemann Sørensen, Jørgen 2006. Efficacy. In: J. Kreinath \& J. Snoek \& M. Stausberg (eds.) Theorizing Rituals: Issues, Topics, Approaches, Concepts. Leiden \& Boston: Brill, pp. 523-532.

Santana, Richard W. \& Erickson, Gregory 2008. Religion and Popular Culture: Rescripting the Sacred. Jefferson: MacFarland and Company Publishers.

Schechner, Richard 1994. Ritual and Performance. In: T. Ingoldt (ed.) Companion Encyclopedia of Anthropology. London-New York: Routledge, pp. 613-647.

Schieffelin, Edward L. 1985. Performance and the Cultural Construction of Reality. American Ethnologist, Vol. 12, pp. 707-724.

Schieffelin, Edward L. 1996. On Failure and Performance: Throwing the Medium out of The Séance. In: C. Laderman \& M. Roseman (eds.) The Performance of Healing. London-New York: Routledge, pp. 59-89.

Schieffelin, Edward L. 1998. Problematizing performance. In: F. Hughes-Freeland (ed.) Ritual, Performance, Media. London \& New York: Routledge, pp.194-207.

Tambiah, Stanley J. 1985. A Performative Approach to Ritual. Culture, Thought and Social Action. Cambridge \& London: Harvard University Press, pp. 123-166.

Trexler, Richard 2003. Reliving Golgotha. The Passion Play in Iztapalapa. Cambridge \& London: Harvard University Press.

Turner, Victor 1982. From Ritual to Theatre. The Human Seriousness of Play. New York: PAJ Publications.

Turner, Victor 2002. Liminality and Communitas. In: M. Lambek (ed.) A Reader in the Anthropology of Religion. Oxford: Blackwell Publishing, pp. 358-374.

Turner, Victor \& Turner, Edith 1978. Image and Pilgrimage in Christian Culture. United States of America: Columbia University Press.

Zowczak, Magdalena 2008. Między tradycją a komercją. [Between Tradition and Commercialism.] Znak, Vol. LX, No. 3, pp. 31-44. 